\title{
DISTINGUISHING CHARACTERISTICS ON OSSA SESAMOIDEA PHALANGIS DISTALIS IN CATTLE (BOS PRIMIGENIUS F. TAURUS LINNÉ 1758)
}

\author{
C. ČRVENÝ \\ Department of Veterinary Anatomy, Histology and Embryology, University of Veterinary \\ Science, 61242 Brno
}

Received February 2, 1989

\begin{abstract}
Červený C.: Distinguishing Characteristics on Ossa Sesamoidea Phalangis Distalis in Cattle (Bos primigenius f. taurus Linné 1758). Acta vet. Brno, 59, 1990: 101-110.

We studied and measured the ossa sesamoidea phalangis distalis on all digits in fourteen female adult individuals of the Bohemian Pied breed. The animals were 3 to 12 years of age.

Adspection of external anatomical characteristics does not allow safe determination of the appurtenance of sesamoid bones of distal phalanges either to respective digits of limbs or to limbs unless we know at least one of the following attributes. If we know the appurtenance of the sesamoid bone to the digit, we can decide from the position and location of anatomical formations its appurtenance either to the right or the left limb, and vice versa. The appurtenance of the sesamoid bone of the distal phalanx of the digit to thoracic or pelvic limbs can be assessed by adspection of the shape and size of the facies flexoria and later confirmed osteometrically.

On the basis of our osteometric observations, the appurtenance of sesamoid bones of distal phalanges to digits and thoracic and pelvic limbs on the basis of mutual comparisons of ascertained values for the height, width and length of bones.

The appurtenance of the sesamoid bone of the dista phalanx to the thoracic or pelvic limbs can best be determined on the basis of their height (sesamoid bones of distal phalanges belonging to the thoracic limb are longer).

Sesamoid bones of the distal phalanx of the third and fourth digit of the thoracic limb is primarily distinguishable for its width and height (the sesamoid bone of the distal phalanx of the fourth digit is narrower and lower).

To distinguish between the same bones of the pelvic limb, their length and width can be used (the sesamoid bone of the fourth digit is narrower and lower).

For an accurate identification of individual sesamoid bones of distal phalanges of cattle digits we must turn to osteometry and fully use the anatomical characteristics described to achieve a conclusive detailed identification of bones. The distinguishing characteristics on ossa sesamoidea pahalngis distalis in cattle discussed here have supplemented the data of comparative and veterinary anatomy and represent an important tool of archaeological osteozoology.
\end{abstract}

Cattle, digits, ossa sesamoidea phalangis distalis, anatomical characteristics, osteometry

Basic anatomical information on the skeleton of domestic animals and its individual parts belongs among the oldest data in veterinary anatomy. It is included in classical as well as more recent monographs and textbooks of veterinary anatomy (Martin and Schauder 1934; Ellenberger and Baum 1947; Vokken et al. 1961; Barone 1966; Nickel et al. 1977; Ashdown et al., 1984 a o.). These monographs also give basic information on interspecies characteristics on the skeleton in the cattle, but their description of some smaller bones, such as the sesamoid bones, is far from exhaustive. Literary data on these small bones cannot help to achieve accurate identification or differentiation. We gave a detailed anatomical description of sesamoid bones of proximal phalanges and their osteometry in the cattle in two consequent publications (Červený 
$1985 \mathrm{ab}$ ). Typical anatomical formations on sesamoid bones of proximal phalanges and osteometric data of these bones allow them to be distinguished and their appurtenance to the digit and limb determined. Typical distinguishing characteristics on the phalanges of digits in the domestic and wild pig were determined by Kratochvil (1973). He also made a comparison of osteometric data of phalanges in the recent and historical cattle (Kratochvil 1987) and set also their basic distinguishing characteristics.

A literary survey showed the need to amplify distinguishing characteristics on the cattle skeleton autopodium to include anatomical and osteometric data on sesamoid bones of the distal phalanx. This also was our aim in the present paper.

\section{Materials and Methods}

Our observations were made using all the digits of the thoracic and pelvic limbs of 14 Bohemian Pied cows aged 3 to 12 years. The autopodia obtained were processed osteologically using maceration by boiling, bleaching in hydrogen peroxide and long-term drying at room temperature.

We studied the shape of the sesamoid bone, its surface anatomical arrangement and internal macrostructure. Internal structure was studied using ground sections of sesamoid bones in three mutually perpendicular planes. Finally, we measured the bones, and their osteometric data were listed in comprehensive tables. The measuring methods were based on proven metric methods according to Duerst (1930). We studied: 1. Maximum height - proximodistal dimension, the maximum distance between the facies proximalis and the facies distalis. 2. Maximum width mediolateral dimension, the maximum distance between facies axialis and facies abaxialis and 3. Maximum length - dorsopalmar (dorsoplantar) dimension, the maximum distance between facies articularis and facies flexoria. When measurements of the maximum height and width of bones were made, the articular surface (facies articularis), namely its larger (axial) section, of the bones were placed on a flat plate and the data were read on a vernier micrometer with prismatic tips. The vernier micrometer was placed with its tips perpendicular to the plate so that the maximum dimensions of the bones could be measured and the axes of the measurements were mutually perpendicular. When measurements lof the maximum length (average) were made, the sesamoid bone was placed on its facies distalis and the vernier micrometer was applied in such a way that the maximum length of the bone measured, which is perpendicular to the two dimensions measured before, could be ascertained.

The metric data thus obtained were recorded in tables and their statistical evaluation was carried out. For the evaluation of individual metric data we used the basic statistical characteristics arithmetic mean, standard error of the mean, standard deviation, variation coefficient and variance. T-test was used to study the significance of differences between individual characteristics measured. A more detailed survey of the material processed is in Table 1.

Table 1

Material used in the study

\begin{tabular}{|c|c|c|}
\hline $\begin{array}{c}\text { Sample } \\
\text { No. }\end{array}$ & $\begin{array}{c}\text { Age } \\
\text { years }\end{array}$ & $\begin{array}{c}\text { Body mass } \\
\mathbf{k g}\end{array}$ \\
\hline 1 & 6 & 610 \\
2 & 9 & 530 \\
3 & 10 & 575 \\
4 & 5 & 567 \\
5 & 4 & 712 \\
6 & 12 & 654 \\
7 & 4 & 428 \\
8 & 8 & 667 \\
9 & 4 & 515 \\
10 & 3 & 430 \\
11 & 7 & 523 \\
12 & 5 & 485 \\
14 & 9 & 480 \\
& 3 & \\
\hline
\end{tabular}



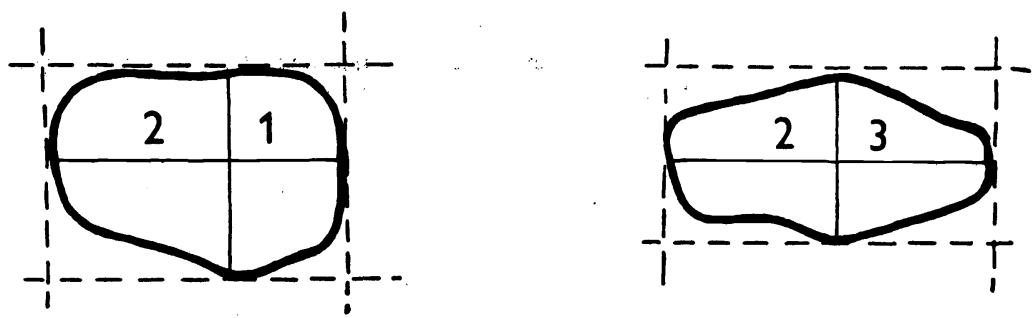

Fig. 1. The method of measuring the maximum height and width of the os sesamoideum phalangis distalis. View of the facies flexoria (palmar and plantar aspects). 1 - maximum bone height, 2 - maximum bone width.

Fig. 2. The method of measuring the maximum length of the os sesamoideum phalangis distalis. Proximal view of the bone measured. 2 - maximum bone width, 3 - maximum bone length.

\section{Results}

The os sesamoideum phalangis distalis in cattle is a small flattened bone, prismatic in shape, with two larger and four narrower surfaces. Its long axis is positioned obliquely in the axial - distal direction. It is placed on the third and fourth digits of the thoracic limb palmarly and on the pelvic limb plantarly from the distal phalanx. Its dorsally placed articular surface it participates with the articular surface of their distal phalanx in forming the articular cavity for the articulatio interphalangea distalis. This cavity accommodates the trochlea of the middle phalanx. Os sesamoideum phalangis distalis is placed in the wall of the articular capsule of the joint - articulatio interphalangea distalis, with short firm ligaments connecting it with surrounding bones.

On all of the sesamoid bones of the distal phalanx, the following surfaces can be distinguished: facies articularis, facies flexoria, facies proximalis, facies distalis, facies axialis and facies abaxialis.

Facies articularis (Fig. 3) - the articular surface is covered completely with articular cartilage. It is an oval narrowed in the middle. In its narrowed part it forms a sagittally positioned ridge, which divides the articular surface into two parts, the axial being the bigger and deeper of the two. The abaxial one is markedly shallower and slopes towards the abaxial surface of the bone. All of the articular

Table 2

Statistical values obtained from the measurement of ossa sesamoidea phalangis distalis of the right thoracic limb

\begin{tabular}{|c|c|c|c|c|c|c|}
\hline \multicolumn{2}{|c|}{$\begin{array}{l}\text { Os sesamoideum } \\
\text { phalangis distalis }\end{array}$} & $\min .-\max$. & $\overline{\mathbf{x}}$ & $\mathrm{s}_{\overline{\mathbf{x}}}( \pm)$ & $\mathbf{s}( \pm)$ & $\mathbf{v}(\%)$ \\
\hline $\begin{array}{l}\text { DIG. } \\
\text { IV. }\end{array}$ & $\begin{array}{l}\text { height } \\
\text { width } \\
\text { length }\end{array}$ & $\begin{array}{l}14.8-18.9 \\
25.1-29.2 \\
11.2-14.0\end{array}$ & $\begin{array}{l}17.57 \\
27.28 \\
12.80\end{array}$ & $\begin{array}{l}0.28 \\
0.30 \\
0.20\end{array}$ & $\begin{array}{l}1.07 \\
1.14 \\
0.78\end{array}$ & $\begin{array}{l}6.08 \\
4.17 \\
6.09\end{array}$ \\
\hline $\begin{array}{l}\text { DIG. } \\
\text { III. }\end{array}$ & $\begin{array}{l}\text { height } \\
\text { width } \\
\text { length }\end{array}$ & $\begin{array}{l}15.9-20.8 \\
26.9-30.7 \\
11.5-14.7\end{array}$ & $\begin{array}{l}18.8 \\
28.9 \\
12.9\end{array}$ & $\begin{array}{l}0.26 \\
0.29 \\
0.21\end{array}$ & $\begin{array}{l}1.01 \\
1.11 \\
0.80\end{array}$ & $\begin{array}{l}5.37 \\
3.89 \\
6.20\end{array}$ \\
\hline
\end{tabular}


Table 3

Statistical values obtained from the measurement of ossa sesamoidea phalangis distalis of the right pelvic limb

\begin{tabular}{|l|l|l|l|l|l|l|}
\hline \multicolumn{2}{|c|}{$\begin{array}{c}\text { Os sesamoideum } \\
\text { phalangis distalis }\end{array}$} & $\begin{array}{c}\mathrm{R} \\
\min .-\max .\end{array}$ & $\overline{\mathbf{x}}$ & $\mathrm{s}_{\overline{\mathbf{x}}}( \pm)$ & $\mathrm{s}( \pm)$ & $\mathrm{v}(\%)$ \\
\hline DIG. & height & $14.5-17.1$ & 16.35 & 0.21 & 0.82 & 5.01 \\
IV. & width & $26.9-30.1$ & 28.33 & 0.29 & 1.10 & 3.88 \\
& length & $11.2-13.9$ & 12.4 & 0.21 & 0.80 & 6.45 \\
DIG. & height & $14.9-17.8$ & 16.63 & 0.20 & 0.76 & 4.57 \\
III. & width & $25.8-29.9$ & 28.35 & 0.32 & 1.23 & 4.33 \\
& length & $11.9-14.1$ & 12.81 & 0.17 & 0.65 & 5.07 \\
\hline
\end{tabular}

surfaces of the bone are bordered with a distinctive edge which passes distally to facies distalis and borders there a small articular surface - facies articularis distalis, joining the sesamoid bones of the distal phalanx with the phalanx distalis of the pertinent digit. The facies articularis of sesamoid bones of distal phalanges on pelvic limbs is narrower, slimmer than on thoracic limbs. Fig. 3 to Fig. 10 are placed at the end of the volume.

Facies flexoria (Fig. 4) - the flexor surface is on the palmar or plantar sidle of the bone respectively, and is also an oval narrowed in the middle, but larger than the articular surface. It is bordered with a lumpy ridge, forming a sharp edge on its distal end. The whole surface is smooth, and palmarly (plantarly) convex in the vertical and sagittal directions. A sagittal ridge extends approximately in the middle of this surface, dividing the flexor surface into upper axial and lower abaxial parts. In the horizontal direction both flexor surfaces are slightly concave, and together with the sagittal ridge they form shallow grooves in which the shape-adjusted tendon of the deep flexor muscle of fingers moves.

Facies flexoria is narrower and thinner on sesamoid bones of distal phalanges of the pelvic limb than on the thoracic limb.

Facies proximalis (Fig. 5) - the proximal surface is narrow and uneven. The axial and abaxial parts of this surface feature prominent tuberosity serving for the attachment of lig. sesamoideum collaterale. Near the dorsal end it forms a pit with a triangular circumference reaching to the top of the sagittal ridge of the articular surface. The bottom of the pit features numerous foramina nutritiva. The pit is lined with synovial membrane and is incorporated to the acetabulum of the articulatio interphalangea distalis.

Facies distalis (Fig. 6) - the distal surface of the sesamoid bone of the distal phalanx is broader than the proximal one and is rough, too. Its circumferential edges are S-shaped. At the abaxial end of the narrow surface there is an elevated tuberosity which farther on forms a tuberosity of the abaxial surface of this bone. Near the end of the abaxial half of this surface there is a small flat arc deltoid surface - facies articularis distalis, providing connection with the facies articularis sesamoidea of the distal phalanx. The remaining part of the distal surface is formed by a groove with uneven surface at its bottom. This groove broadens axially.

Facies axialis - the axial surface is an elongated pentagon, its top is oriented distally. In shallow pits foramina nutritiva are discernible. The whole surface is corrugated, with proximal and distal attachments of lig. sesamoideum collaterale and lig. ungulosesamoideum axiale, respectively. 
TS IV. TS III.

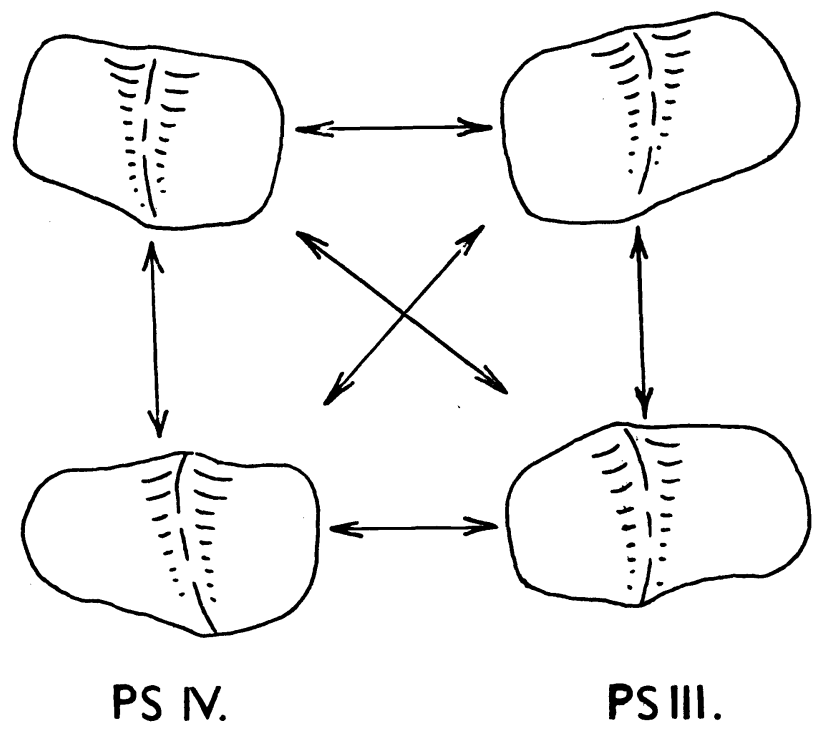

Fig. 11. Methods of comparing the shape and size of individual sesamoid bones of distal phalanges of the third and fourth digits of the pelvic and thoracic limbs in cattle. TS III - os sesamoideum phalangis distalis digiti tertii membri thoracii simistri, TS IV - os sesamoideum phalangis distalis digiti quarti membri thoracici sinistri, PS III - os sesamoideum phalangis distalis digiti tertii membri pelvini sinistri, PS IV - os sesamoideum phalangis distalis digiti quarti membri pelvini sinistri.

Facies abaxialis - the abaxial surface is lower and longer than the axial one, it is clearly convex and rough. Also found here are proximal and distal attachments of lig. sesamoideum collaterale and lig. ungulosesamoiceum abaxiale, respectively.

The internal arrangement of the sesamoid bone of the distal phalanx is characteristic for small bones. The basis is formed by spongy bone with no central cavity. The spongy bone is surrounded with a mentle of compact bone $1-5 \mathrm{~mm}$ thick, depending on its location. The thickest mantle is found at the level of the abaxial surface and the distal end of the axial surface, the thinnest near the facies distalis, facies proximalis and facies axialis proximally (Figs. 7,8).

A list of arithmetic means of values in the characteristics studied, including their statistical evaluation, is presented in Tables 2 and 3.

The variability of individual characteristics was assessed on the basis of the variation coefficient. The height of bones is one of the characteristics with highest variability, its variation coefficient being in the range of $3.39 \%-6.87 \%$. The second most variable metric value was the width. In this case, the maximum variation coefficient was $4.78 \%$, the minimum value was $3.94 \%$.

After a statistical evaluation of individual metric data we investigated the significance of differences between characteristics studied (see Tab. 4). The comparison was made on the thoracic and pelvic limbs according to a pattern shown in Fig. 11.

The highest number of statistically significant cases was found in differences in height values. The difference between the sesamoid bone of distal phalanges 
Table 4

Statistical significance in the characteristics using t-test $(P<0.01)$

\begin{tabular}{|c|c|c|c|}
\hline $\begin{array}{l}\text { Bones under } \\
\text { comparison }\end{array}$ & Height & Width & Length \\
\hline TD III. $\times$ TD IV & $\begin{array}{l}\text { highly } \\
\text { significant }\end{array}$ & $\begin{array}{l}\text { highly } \\
\text { significant }\end{array}$ & 0 \\
\hline PD III. $\times$ PD IV & significant & 0 & $\begin{array}{l}\text { highly } \\
\text { significant }\end{array}$ \\
\hline TD III. $\times$ PD III. & $\begin{array}{l}\text { highly } \\
\text { significant }\end{array}$ & significant & $\begin{array}{l}\text { highly } \\
\text { significant }\end{array}$ \\
\hline TD IV. $\times$ PD IV & $\begin{array}{l}\text { highly } \\
\text { significant }\end{array}$ & $\begin{array}{l}\text { highly } \\
\text { significant }\end{array}$ & $\begin{array}{l}\text { highly } \\
\text { significant }\end{array}$ \\
\hline
\end{tabular}

TD - membrum thoracicum dextrum, digitus III., IV.

PD - membrum pelvinum dextrum, digitus III., IV.

of the third and fourth digits on the pelvic limb. Highly significant statistical differences were found between heights of sesamoid bones of distal phalanges of the third and fourth digits on the thoracic limb, sesamoid bones of the distal phalanx of the third digits on the thoracic and pelvic limbs, and sesamoid bones of distal phalanges on the thoracic and pelvic limb.

Highly significant statistical differences in width were found in two cases. One was the difference between sesamoid bones of the distal phalanx of the third and fourth digits of the thoracic limb, the other the difference between sesamoid bones of the distal phalanx of the fourth digit of the thoracic and pelvic limbs. Statistically significant difference was found between sesamoid bones of the distal phalanx of the thoracic and pelvic limbs.

When a comparison of length values was made, statistically highly significant differences were found in three cases. They were the differences between sesamoid bones of the distal phalanx of the third and fourth digits on the pelvic limb, the difference between the length of sesamoid bones of the distal phalanx of the fourth digits on the thoracic and pelvic limbs.

\section{Discussion}

The information on the anatomical structure and arrangement of sesamoid bones of distal phalanges of individual digits on all four limbs supplement the basic data provided by classical veterinary anatomy handbooks and monographs (Kolda 1936; Ellenberger and Baum 1947; Baron 1966; Getty 1972; Nickel et al. 1977 a. o.). Detailed description of anatomical formations on the bones studied and of topographic relations between these anatomical formations allows only basic identification of these tiny bones of the digital skeleton. While Dottrens (1946) described anatomical distinguishing characteristics of individual digits in cattle, and Červený (1985a) specified shape characteristics for individual sesamoid bones of proximal phalanges of digits in cattle alowing identification of the bones, sesamoid bones of distal phalanges resisted identification or 
their appurtenance to individual digits or limb on the basis of anatomical characteristics. Neither shape nor anatomical characteristics of sesamoid bones of the distal phalanx of the third or the fourth digits of the hand or foot are different enough to allow identification of individual bones without knowing at least whether the bone studied belongs to the third or to the fourth digit, or whether it belongs to either the left or the right limb. All sesamoid bones of distal phalanges have basically the same shape, with only slight differences in dimensions and location of anatomical formations. Typical locations of anatomical formations may allow the bone to be correctly included into the skeleton of the third or the fourth digit, to be classified as a left or right bone. After a long study by adspection and comparing a larger number of sesamoid bones of distal phalanges of the hand or foot it is possible to tentatively identify sesamoid bones of distal phalanges of thoracic or pelvic limbs in a set of bones of one individual by sight alone and distinguish between sesamoid bones of the distal phalanx of the third and the fourth digits of the thoracic limb. This relatively reliable identification can be based on a comparison of the size of flexor surfaces - facies flexoria - on all four right or left bones, using adspection only. In order that a more exact method is used to substantiate this estimation, we used metric evaluation to achieve a more accurate identification.

Osteometry of sesamoid bones is not routinely used in the literature. Not even Duerst's handbook (1930) suggests the use of the method for measuring these small bones. Driesh(1976) processed osteometrically the ossa sesamoidea phalangis distalis in the horse. Beside anatomical characteristics, we successfully employed osteometry as an additional criterion to distinguish between sesamoid bones of proximal phalanges of digits in cattle (Červený 1985b). After successful experience with sesamoid bones of proximal phalanges of the digits in cattle we can say taht application of osteometry on the material studied was successful and that results statistically processed when significance of differences of characteristics studied were in the case of sesamoid bones of distal phalanges even more accurate than in the case of sesamoid bones of proximal phalanges (Červený 1985b). Statistical evaluation of characteristics investigated on ossa sesamoidea phalangis distalis showed that comparison of dimensions of individual bones is in the majority of characteristics highly statistically significant (Table 4). This, however, does not hold true about the statistical evaluation of osteometric characteristics on the ossa sesamoidea phalangis proximalis (Červený 1985b), when high statistical significance of individual characteristics investigated was established in two cases only, namely the height and width of sesamoid bones of proximal phalanges. When trying to identify sesamoid bones of the phalanx, the correct procedure must be observed scrupulously because the differences between values measured on these small bones are very small and they could be distorted if bones are placed incorrectly on the support plate or if the vernier micrometer is not set at planes mutually perpendicular. When measurements are made, any exostoses that may occur at the bone edges must be taken into account, because they could also influence and distort the results. Comparison of data ascertained on sesamoid bones of distal phalanges of the right and left digits showed that the differences are very small and statistically insignificant.

Accurate identification of individual sesamoid bones of distal phalanges of digits in cattle must be based on osteometric values of these bones. Osteometry allows us to distinguish between sesamoid bones of the pelvic and thoracic limbs and determine their appurtenance to either the third or the fourth digit. On the 
basis of topographic relations between anatomical formations described on sesamoid bones of distal phalanges it can then be decided whether the bone investigated comes from the right or the left limb.

\section{Rozlišovací znaky na ossa sesamoidea phalangis distalis u skotu (Bos primigenius F. taurus Linné 1758)}

Prostudovali jsme a proměřili ossa sesamoidea phalangis distalis na všech prstech u čtrnácti dospělých kusủ českého strakatého skotu samičího pohlaví. V souboru byli zastoupení jedinci ve věku od 3 do 12 roků.

Podle zevních anatomických znaků adspekcí nebylo možné bezpečně určit př́slušnost sezamských kostí distálních článkủ prstů $\mathrm{k}$ jednotlivým prstům končetin ani ke končetinám, pokud jsme neznali alespoň jeden $z$ těchto atributů. Pokud známe přislušnost sezamské kosti $\mathrm{k}$ prstu, lze podle postaveni a uložení anatomických útvarů určit jeji př́slušnost $\mathrm{k}$ pravostranné či levostranné končetině a naopak. Př́islušnost sezamské kosti distálního článku prstu $\mathrm{k}$ hrudní nebo pánevní končetině je možné adspekcí podle tvaru a velikosti facies flexoria odhadnout a $\mathrm{v}$ následnosti osteometricky potvrdit.

$\mathrm{Na}$ základě našich osteometrických pozorování bylo možné určit př́slušnost sezamských kostí distálních článků prstů $\mathrm{k}$ prstům a hrudním či pánevním končetinám a to na základě vzájemného porovnání naměřených hodnot výšky, šířky a délky kostí.

Pro určeni prríslušnosti sezamské kosti distálního článku prstu $\mathrm{k}$ hrudní končetině lze využít především výšky (sezamské kosti distálních článků prstů $\mathrm{z}$ hrudní končetiny jsou vyšší).

Sezamské kosti distálních článků třetího a čtvrtého prstu hrudni končetiny jsme rozlišovali především podle hodnot šírky a výšky (sezamská kost distálního článku čtvrtého prstu je užší a nižší).

Pro rozlišení stejných kostí na pánevní končetině jsme využivali $k$ rozlišení hodnot délky a výšky (sezamská kost čtvrtého prstu je kratší a nižší).

Pro přesnou identifikaci jednotivých sezamských kostí distálních článků prstů skotu je třeba vycházet $\mathrm{z}$ osteometrie a $\mathrm{v}$ plné míre využít $\mathrm{k}$ detailnímu konečnému určení kostí popsané anatomické podrobnosti. Popsané rozlišovací znaky na ossa sesamoidea phalangis distalis u skotu doplnily údaje srovnávací a veterinární anatomie a jsou významnou pomůckou pro archeologickou osteozoologii.

\section{Различительные черты на ossa sesamoidea phalangis distalis крүпного рогатого скота (Bos primigenius F. taurus Linné 1758)}

Занимались изучением и измерением ossa sesamoidea phalangis distalis всех пальцев у четырнаднати взрослых самок чешской пестрой породы. В группе были представлены особи в возрасте 3-12 лет.

По внешним анатомическим признакам нельзя надежно определить принадлежность сезамовидных костей дистальных фаланг пальцев к отдельным пальцам конечностей, ни к конечностям, не зная хотя бы один из упомянутых атрибутов. Зная принадлежность сезамовидной кости к пальцу, можно по положению и расположению анатомических 
форм определить ее принадлежность к правой или левой конечностям и наоборот. Принадлежность сезамовидной кости дистальной фаланги пальца к передней или задней конечностям можно определить по форме и величине facies flexoria и в дальнейшем подтвердить остеометрически.

Исходя из наших остеометрических наблюдений, можно определить принадлежность сезамовидных костей дистальных фаланг пальцев к пальцам, передним и задним конечностям, а именно на основе взаимного сопоставления измеренных величин высоты, ширины и длины костей.

Для определения принадлежности сезамовидной кости дистальной фаланги пальца к передней или задней конечностям можно воспользоваться прежде всего высотой (сезамовидные кости дистальных фаланг пальцев передней конечности выше).

Сезамовидные кости дистальных фаланг третьего и четвертого пальцев передней конечности различаем прежде всего по ширине и высоте (сезамовидная кость дистальной фаланги четвертого пальца уже и ниже).

Для различения одинаковых костей на задней конечности используют длину и высоту (сезамовидная кость четвертого пальца короче и ниже).

С целью точного определения отдельных сезамовидных костей дистальных фаланг пальцев крупного рогатого скота следует исходить из остеометрии и полностью для детального окончательного определения костей использовать приведенные анатомические подробности. Упомянутые различительные черты на сезамовидных костях дистальных фаланг крупного рогатого скота дополнили данные сравнительной и ветеринарной анатомии, став немаловажной подмогой археологической остеозоологии.

\section{References}

ASHDOWN, R. - DONE, S.: Topografische Anatomie der Wiederkäuer. F. Enke Verlag, Stuttgart, $1984,233 \mathrm{p}$.

BARONE, R.: Anatomie comparée des Mammifères domestiques. Tome premier, Osteologie. Lab. d'anatomie Ecole Nationale Vèterinaire, Lyon, 1966, $811 \mathrm{p}$.

CERVENÝ, C.: Anatomical characteristics on the ossa sesamoidea phalangis proximalis in cattle (Bos primigenius f. taurus Linné 1758). Acta vet. Brno, 54, 1985a: 3-22

CERVENÝ, C.: Osteometry of the ossa sesamoidea phalangis proximalis in cattle (Bos primigenius f. taurus Linné 1758). Acta vet. Brno, 54, 1985b: 119-128

DOTTRENS, E.: Etude préliminaire: Les phalanges osseuses de Bos Taurus domesticus. Rev. Suisse de Zool., 53, 1946: 739-744

DRIESCH, A.: Das Vermessen von Tierknochen aus vor- und frügeschichtlichen Siedlungen. Univ. München, München, 1976, 114 p.

DUERST, J. U.: Vergleichende Untersuchengsmethoden am Skelett bei Säugern. In: ABDERHALDEN, E.: Handbuch der biologischen Arbeitsmethoden. Urban und Schwarzenberg, Berlin und Wien, 1930, $887 \mathrm{p}$.

ELLENBERGER, W. - BAUM, H.: Handbuch der vergleichenden Anatomie der Haustiere, Springer Verlag, Berlin, 1943, $1155 \mathrm{p}$.

GETTY, R.: The Anatomy of the Domestic Animals. Vol. 1, W. B. Saunderes Company, Philadelphia-London-Toronto, 1975, $1211 \mathrm{p}$.

KOLDA, J.: Srovnávaci anatomie domácích zviřat se zřetelem $\mathrm{k}$ anatomii člověka. I. část obecná, II. nauka o kostech a chrupavkách. Novina, Brno, 1936, 914 p.

KRATOCHVfL, Z.: Discriminative characteristics on the acropodium of domestic and the wild pig (Sus scrofa f. domestica L., Sus scrofa L.) Acta vet. Brno, 42, 1973: 109-133 
KRATOCHVfL, Z.: Tierknochenfunde aus der Siedlung Mikulčice (III). Acta Sc. Nat. Brno, 21, (11), 1987: $1-50$

MARTIN, P.-SCHAUDER, W.: Lehrbuch der Anatomie der Haustiere. III. Band, Bewegungsapparat der Hauswiederkäuer. Schickhard u. Ebner, Stuttgart, 1934, 135 p.

NICKEL, R. - SCHUMMER, A.-SEIFERLE, E.: Lehrbuch der Anatomie der Haustiere. Band I. Bewegungsapparat, Paul Parey, Berlin und Hamburg, 1977, 539 p.

VOKKEN, G. G. - GLAGOLEV, P. A. - BOGOLJUBSKIJ, S. N.: Anatomija domašnich životnych. Gos. izd. ,,Vysšaja škola“", Moskva, 1961, 390 p. 


\section{Plate VI.}

Červený Č.: Distinguishing Characteristics ... pp. 101-110.
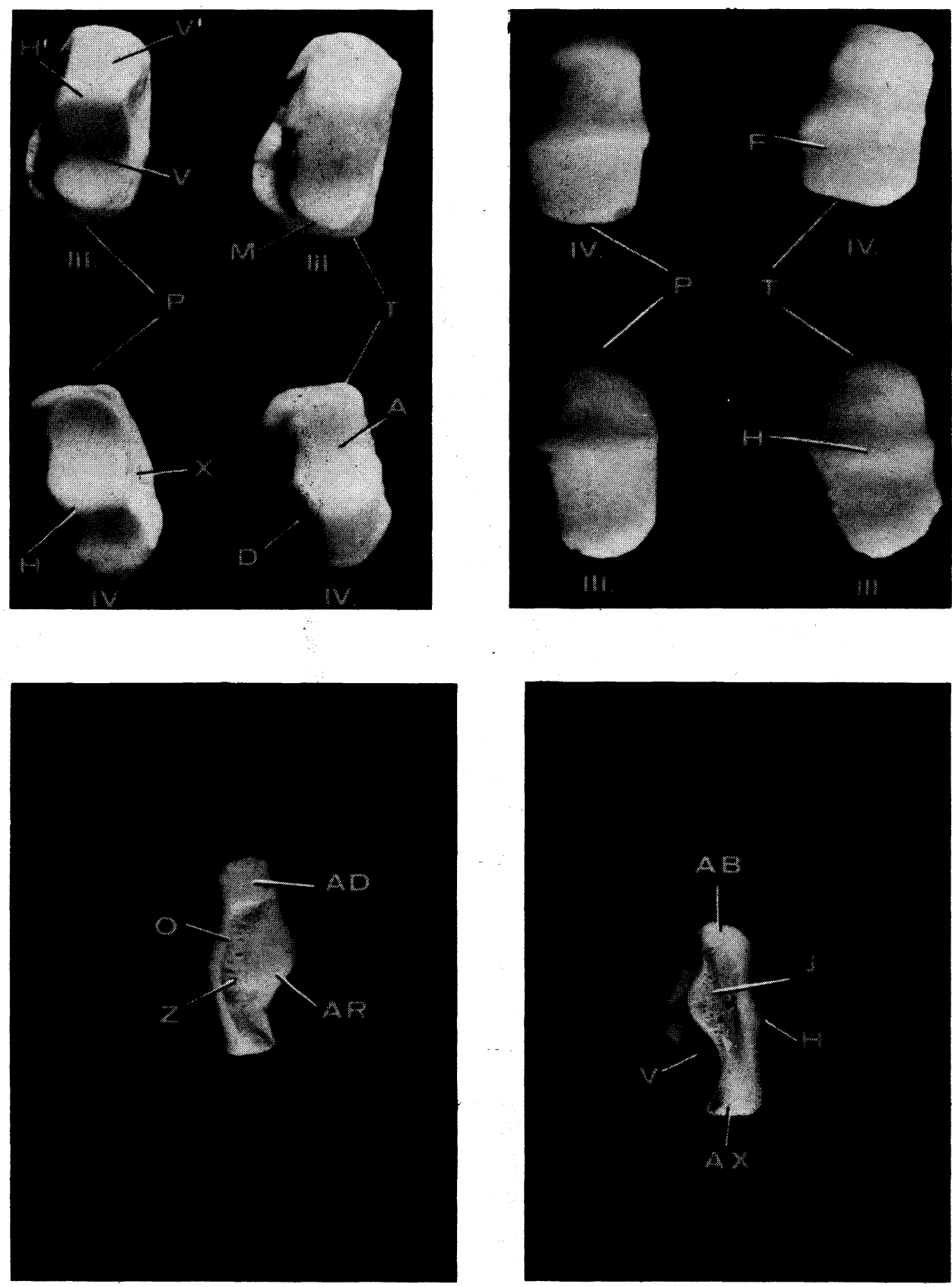
Plate VI.

Fig. 3. Ossa sesamoidea phalangis distalis of the third and fourth digit of the left thoracic and pelvic limbs in cattle. View of the facies articularis. $T$ - ossa sesamoidea phalangis distalis of the pelvic limb, P - ossa sasamoidea phalangis distalis of the pelvic limb, III - ossa sesamoidea phalangis distalis digiti tertii, IV - ossa sesamoidea phalangis distalis digiti quarti. A - facies articulare, $\mathrm{H}^{\prime}$ - sagittal ridge of the articulare surface, $\mathrm{X}$ - facies proximalis, $\mathrm{M}$ - circumferential edge of the articular surface, $\mathrm{V}$ - bigger axial and smaller abaxial (V) depression in the articular surface, D - facies distalis.

Fig. 4. Ossa sesamoidea phalangis distalis of the third and fourth digits of the left thoracic and pelvic limbs in the cattle. View of the facies flexoria. T - ossa sesamoidea phalangis distalis of the thoracic limb, P-ossa sesamoidea phalangis distalis of the pelvic limb, III - ossa sesamoidea phalangis distalis digiti tertii, IV - ossa sesamoidea phalangis distalis digiti quarti, $\mathbf{H}$ - sagittal ridge of the articular surface, $\mathrm{F}$ - facies flexoria, its higher arial part.

Fig. 5. Os sesamoideum phalangis distalis digiti IV membri pelvini dextri (Bos taurus). View of the facies proximalis. AX - axial and $A B$ - abaxial tuberosity of the proximal area, $J$ - pit in the proximal area, $\mathrm{H}$ - sagittal ridge of the articular surface, $\mathrm{V}$ - bigger axial depression in the articular area.

Fig. 6. sesamoideum phalangis distalis digiti IV membri pelvini dextri (Bos taurus). View of the facies distalis. AR - facies articularis distalis, $A D$ - abaxial tuberosity, $\mathrm{Z}$ - groove of the distal area, $\mathrm{O}$ - distal edge of the articular surface.

\section{Plate VII.}

Fig. 7. The distrubution of the compact bone and spongy bone in the mediolateral vertical crosssection of the sesamoid bone of the distal phalanx of the third digit of the right pelvic limb in the cattle at about half its length. View of the plantar side of the section. D - facies distalis, $\mathrm{X}$ - facies proximalis, $\mathrm{B}$ - facies abaxialis, $\mathrm{C}$ - facies axialis, $\mathrm{K}$ - compact bone, $\mathrm{S}$ - spongy bone.

Fig. 8. The distribution of the compact bone and its spongy bone in the mediolateral horizontal cross-section of the sesamoid bone of the distal phalanx of the fourth digit of the right pelvic limb in cattle in the distal third of its length. View of the proximal side of the section. A - facies articularis, $\mathrm{B}$ - facies abaxialis, $\mathrm{C}$ - facies axialis, $\mathrm{K}$ - compact bone, $\mathrm{S}$ - spongy bone.

Fig. 9. Ossa sesamoidea phalangis distalis in cattle. View of the facies flexoria, comparison of bones from pelvic and thoracic limbs. TS III - os sesamoideum phalangis distalis digiti tertii membri thoracici sinistri, PS - os sesamoideum phalangis distalis digiti quarti membri pelvini sinistri. 1 - bone height, adspection of the facies flexoria allows the higher sesamoid bone of the distal phalanx of the pelvic limb to be distinguished from the lower bone of the thoracic limb.

Fig. 10. Ossa sesamoidea phalangis distalis in cattle. View of the facies flexoria, comparison of bones of the third and fourth digits of the pelvic limb. The os sesamoideum phalangis distalis digiti III is broader. TS III - os sesamoideum phalangis distalis digiti tertii membri thoracici sinistri, TS IV - os sesamoideum phalangis distalis digiti quarti membri thoracici sinistri, 2 - bone width. 
Plate VII.
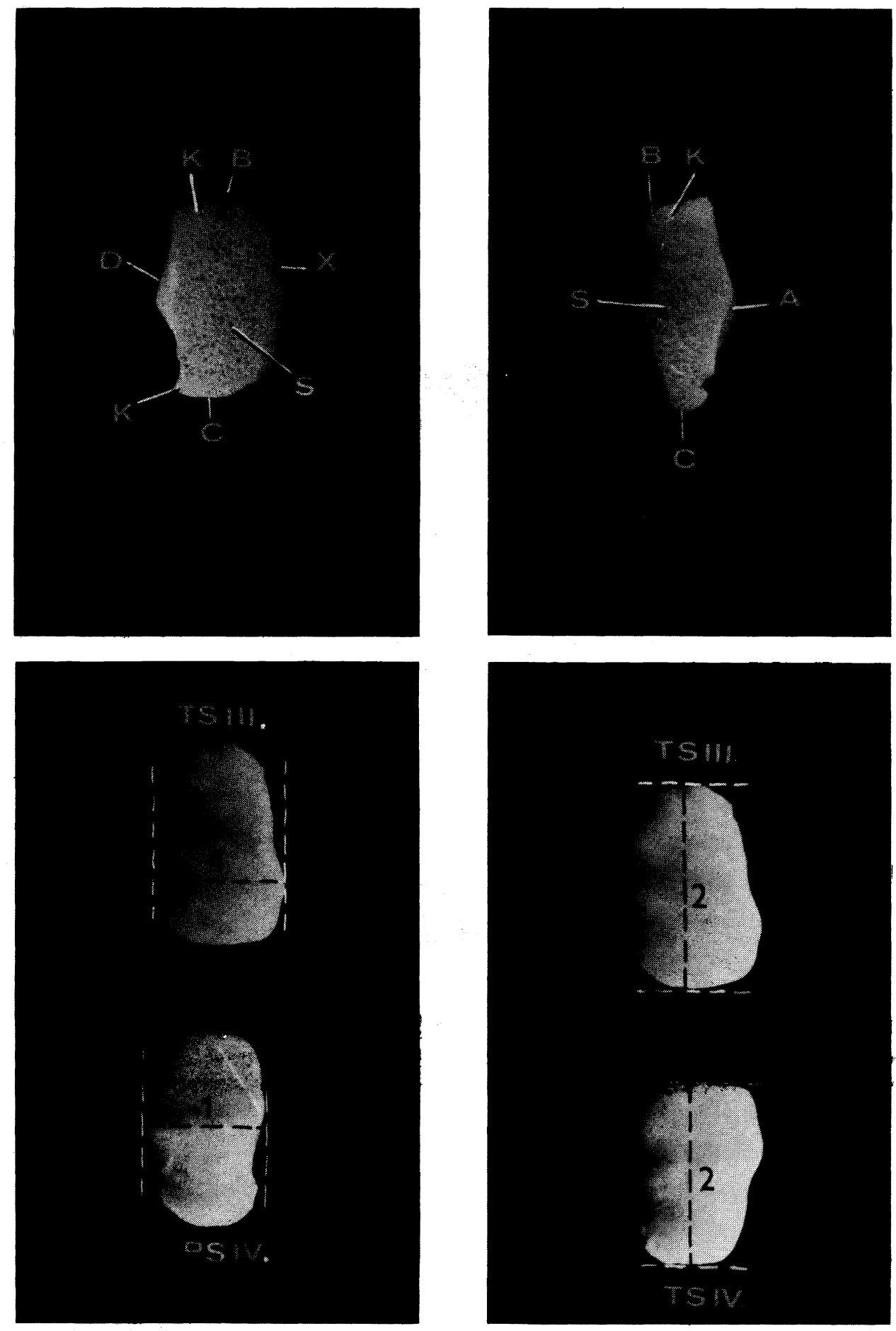